\title{
Exploring the applicability of electronic markets to port governance
}

\author{
Maria A. Lambrou*, Athanasios A. Pallis \\ and Nikitas V. Nikitakos
}

Department of Shipping, Trade and Transport, Business School,

University of the Aegean, 2A, Korai, 82100, Chios, Greece

Fax:+302271035212_E-mail: mlambrou@aegean.gr

E-mail: apallis@aegean.gr E-mail:nnik@aegean.gr

${ }^{*}$ Corresponding author

\begin{abstract}
The paper explores the rationale of embracing e-Governance models as a mean to improve port policy and decision making towards enhanced port performance and competitiveness. The paper establishes both the significance and the applicability of advanced port e-Governance models, based on e-markets typologies. The devised theoretical framework suggests that within the evolving variation of port structures, e-Governance, public-private interorganisational network models and in particular the e-market paradigm provide a great opportunity towards the 'smart networking' of the plurality of port actors, including public port authorities, terminal service providers, shipping companies, logistics and transportation companies, customs and other third parties.
\end{abstract}

Keywords: port policy; port clusters; port devolution; e-government; Information and Communication Technologies; ICT.

Reference to this paper should be made as follows: Lambrou, M.A., Pallis, A.A. and Nikitakos, N.V. (2008) 'Exploring the applicability of electronic markets to port governance', Int. J. Ocean Systems Management, Vol. 1, No. 1, pp.14-30.

Biographical notes: Maria A. Lambrou is an Assistant Professor in e-business with the University of the Aegean, Department of Shipping, Trade and Transport. She received her PhD Degree from the National Technical University of Athens (NTUA), Department of Electrical and Computer Engineering - Computer Science Division, in the area of Service Engineering (1998). She has over 40 publications in the following areas: e-business, e-government, mobile and personal communications, service engineering, pervasive computing and digital shipping applications.

Athanasios A. Pallis is an Assistant Professor (Jean Monnet in European Port Policy), in the Department of Shipping, Trade and Transport, University of the Aegean, Greece. He is the author of books and journal papers examining Port Economics and Policy and the EU Maritime Transport Policy. He is a member of the Port Performance Research Network, the International Association of Maritime Economists, the Special Interest Group Ports and Maritime Transport, World Transport Research Society, the Association for European Transport, the University Association for Contemporary European Studies, and the Network for Communication and Transport Activities Research. He received 
his Undergraduate Degree from Athens University of Economics, Greece (1992), his MA from Exeter University, UK (1993), and his PhD from the University of Bath, UK in 1998.

Nikitas V. Nikitakos is Professor in Shipping Informatics and Communications in the University of the Aegean. He is a graduate of Hellenic Naval Academy (1980) and holds a BSc in Economics (University of Piraeus 1986) and two MSc from Naval Postgraduate School, Monterey, CA, USA (MSc EE and $\mathrm{MSc}$ in Appl. Mathematics). He received a $\mathrm{PhD}$ in Electrical and Computer Engineering from National Technical University of Athens (1996). His research interests include maritime information systems, maritime security, risk management for transportation systems, regional development, port services and security.

\section{Introduction}

The port sector is in a state of transition. Major related changes in the production process include the geographical shift of production, just-in-time manufacturing, supply chains and multimodal transportation integration, and an increased exploitation of new technologies. The widespread development of containerisation, the consequent operational reforms of world shipping (exploration of both economies of scope and economies of size) and the shift of political attitudes and regulatory regimes in favour of less state intervention (privatisation, proposals for the liberalisation of port services provision in the European Union), all contribute towards this transitional phase.

There has been a remarkable variance of port governance and policy restructuring to these, mostly external driven, changes. This variance reflects different approaches on the most appropriate form of port organisation. It results in the simultaneous presence of both public and private forms of port operations, which are governed by public or quasi-public port authorities. This range of these hybrid forms of port organisation is rather well documented (Brooks, 2004; Bichou and Gray, 2005).

Since the introduction of the Electronic Data Interchanges (EDI) systems in the mid-1980s, the port sector has progressively endorsed several new Information and Communication Technologies (ICTs) such as web presence portals, intranets, extranets and support software platforms (i.e., ERPs, Workflow Managements Systems) and communication platforms (i.e., wireless- and sensor-based systems) (Kia et al., 2000).

Surprisingly, the investigation of the significance and the potential of comprehensive e-Governance concepts with specific strategic, operational, and technological implementation and use options, towards the facilitation of port actors' responses to new competitive pressures, is a totally unexplored area.

In this paper, we focus on examining how e-Government and the implementation of specific ICT operational models, such as the port public-private interorganisational networks, and its transition to a pervasive electronic port services paradigm might facilitate the ports adjustment process, and improve the position of the several actors involved in port operations.

The conceptual framework we present may serve in guiding the development of innovative e-Governance models in the multifaced and multiactors sector; it is embedded in theory of port policy, e-Government and e-markets, as regards in particular the nature 
of the contemporary port product, its ICT ramifications, and aspects of port policy reforms towards operational and governance devolution, resulting in hybrid forms of port governance.

The suggested framework proposes an a priori theory for electronic port governance and delineates the rationale and determinants of port multiactors collaborative electronic networks, the enabling mechanisms and infrastructural underpinning for achieving the objectives of joint initiatives (strategic alliances and coordinated relationships) and electronic networks formation. The basic premise is that as the port policy environment perplexes, e-markets as applicable e-Government models offer intriguing possibilities and insights for port policy making and operations.

Our analysis and the theoretical propositions are approached as follows: first, the analysis outlines contemporary port governance issues, and their important institutional, structural, and organisational dimensions, so as to argue on possible evolutionary paths of port entities' and port networks' governance. These port governance elements provide the 'hooks' upon which port actors may hang elements of enacted technology. Secondly, we examine the motivation, relationships and functionality regarding the emerging port interorganisational networks which may be composed of equals, or may have one powerful central actor coupled with other actors relying on the central organisation for resources and information exchange and transactions. In the case of the port sector, the key actor responsible for cluster management is the public port authority. Against this background, the paper primarily suggests a port-authority centred e-Governance network model, based on features of e-markets typologies.

\section{Contemporary port governance challenges}

The changing market context in which ports operate has played a key role in transforming the contemporary port product and inducing major port governance and policy reforms. Fundamental changes in the production and distribution of goods, industrial networks development, unitisation, short product lifecycles, and short time-to-market periods, are all variables that reduce the advantages of proximity to the port and increase the role of logistics (Helling and Poister, 2000). Port users' demand is characterised by a high level of differentiation regarding port services, including cargo and passenger handling, vessel pilotage and towage, vessel traffic management services, safety services, landside and berth services, customs and immigration services, maintenance and repair services, waste disposal, logistics and multimodal transportation services (rail, truck networks), as well as emergency and security services.

The responsiveness of ports to this differentiation conditions their competitiveness. Market shares depend on the provision of complementary, user-driven, value-added, port-related services, which are efficiently supplied in wider geographical areas. The efficient supply of these complementary services does not require the location of the production units within the port zone. Freight corridors expand further and many ports are creating the necessary conditions and infrastructure for setting up networks dedicated to multimodal transportation.

All these developments have led to port product variation and new organisational strategies. With the overall port product becoming a chain of (specialised) interlinking functions (Suykens and van de Voorde, 1998), flexible operational methods stand as a 
means to face the adjustment pressures (Notteboom and Winkelmans, 2001, 2002). The fordist model of port services provision is progressively replaced by the presence of 'new worlds of port services provision that are based on interpersonal relations between service providers and users (Chlomoudis et al., 2003). The organisation and technology of modern production-transportation-distribution processes, which are embedded in a changing macro- and microeconomic framework, demand the presence of flexibilisation and specialisation (Rodrigue, 2005). Specialisation is part of the contemporary scene because port integration in the land-based segments of the chain depends on the presence of several specialised port service providers, which are effectively networked. Flexibilisation represents, a highly differentiated, strongly market- and customer/user-driven mode of producing and providing specialised added-value services. A port adjustment strategy incorporates the simultaneous provision of core services along with the provision of both value-added services and value-added logistics.

The large comprehensive port organisation, which is commonly based on large standardised processes, is outdated. The number of actors within a port complex multiplies both because more types of services are provided and because the same type of services is provided by more than one entity. Competition takes the forms of intraport and intraterminal competition. The former type of competition is a situation where two or more different terminal operators within the same port are vying for the same market and the terminal operator has jurisdiction over an entirely terminal area, for berth to gate, and competes with other terminal operators. The latter refers to companies competing to provide the same services within the same terminal (World Bank, 2000) with concessioning standing as the dominant entry mode in this market. Apart from preventing monopoly pricing, those responsible for port policy design (European Commission, 2004) and port authorities (Pallis and Vaggelas, 2005) advance the introduction of such competition between a plurality of providers of port products/services/facilities, as an engine of innovation and specialisation (de Langen and Pallis, 2006). The monopolistic market structure of port services provision and any single corporate hierarchy are replaced by a network of organisations operating in different worlds of production.

At the same time, the request of port users for the integration of ports in wider hinterlands, the increased number of providers of port services (i.e., different stevedoring companies operating different terminals) and/or value-added logistics within a port needs to participate in broader business interactions. Ports are increasingly clusters consisting of heterogeneous corporations with differentiated core business. Shipping companies, port authorities, port services and logistics providers, shippers, and forwarders, companies specialising in warehousing, railway and road transportation are redefining their strategy goals seeking a new matching framework of their interactions in order to remain competitive and to increase or retain their position in the market. van der Horst and de Langen (2007) give examples of a number of coordination problems, involving several actors and demanding extensive interorganisational planning in a port (Moonen et al., 2005).

In this context, the advent of ICT enables network business models, within which both flexibilisation and specialisation might take place. Port product and processes are considered as 'augmented' products and processes, with their traditional, physical nature being overlaid with an informational and electronic transactions component.

These developments are inextricably linked with the expansion of port hinterlands, and the emerging port regionalisation (Rodrigue and Notteboom, 2005), that is the 
geographical and functional integration of ports in wider regions. Ports attempt to link more efficiently the elements of the supply chain in order to ensure that the needs of the customers are closely met by the suppliers in terms of costs, availability and time. The outcome is the transformation of ports to nodes of complex transportation networks, searching for means to be functionally and geographically integrated systems of locations and flows with the purpose of generating value.

With the rapid and pervasive restructuring of supply chains and of the logistics pathways in which ports are embedded, ports are now elements in value-driven chain systems not simply places with particular, if complex, functions (Paixao and Marlow, 2003; Robinson, 2003). The port captures value for itself and for the chain (i.e., shippers, transportation and third-party service providers), while maritime companies demand further services specialisation within the port area, and firms providing port services are interested in developing strategies to succeed in hugely complex environment and uncertainty.

ICTs are catalysts for the enhanced performance of port value chains, offering benefits such as quicker access to information, improved communication with customers and business partners, better customer service, reduced operational and administrative costs, higher productivity and quality of service. Primarily, strategic goals can be supported including value creation for port stakeholders, and capturing a dominant market position or a viable market niche.

\section{Port governance reforms and actors' coordination}

For all the reasons stated above, port planning is restructured, with new approaches implying a new role to be played by the port authority and a reassessment of the public sector involvement (Mogli and Sanguineri, 2003). Most of the port policy reforms have taken the form of port devolution, which is the transfer of functions or responsibility for the delivery of services from the government to other autonomous port level entities (Brooks, 2004). Within this alternative service delivery process, governments seek to become more customer driven. This new public management is client focused, entrepreneurial, innovative, and intends to:

- lessen centralised bureaucratic control and heighten the use of decentralised quasi-market mechanism

- decouple the government's policy-making function from operations

- increase participation by nongovernment entities in the design and delivery of government programmes and services (Brooks and Cullinane, 2006).

Several European (i.e., Italy, Spain, Greece) and non-European countries (i.e., Australia, Canada) have endorsed such policy reforms searching for the 'best way' to manage and organise a competitive port system.

The range of devolution alternatives adopted within the global ports sector varies (Cullinane and Song, 2002), with the literature avoiding to make assumptions about the inherent superiority of one environment-strategy-structure configuration over any other (Baltazar and Brooks, 2006). More important for this study is the postreform role of the public sector. In public ports, where all regulator and landlord functions fall to the public sector, some, or all, operator functions may be undertaken under contract by the private 
sector, the control of the conditions of operation resides with the government. In the, most commonly observed, partial privatisation case, some operator and/or landlord functions are privatised, usually with the public sector retaining full control of the regulator function. In the less frequently observed case of full privatisation, all of the operator and landlord functions are transferred from the public to the private sector, but the government opts to provide regulator functions. There is widespread agreement that property rights, the existence of public goods, and the presence of externalities stand as valid causes of the existence of some form of public-controlled port authority, even when port privatisation policies prevail.

As a result, hybrid port organisations exist in the intersection of two distinct spheres, the public and the private. Governments move away from the direct delivery of port services, yet they retain policy-making responsibilities, as its autonomous executive organisations (port authorities) establish long-term relationship with private port operators performing services on the basis of management contracts. Limiting the conventional interventionist role, the state operates to a certain extent, as an external agent, which intervenes in the workings of the port economy from a position outside and above the situation of operations and with a view to maximising the common good, even in the context of a private sector port system (Gilman, 2003).

Against this background public and private actors, as well as public or quasi-public port authorities, are in the search of an efficient and effective networking that creates a competitive port community spirit that minimises difficulties in integrating ports with logistics and supply chains and help to establish the essential proactive approach to satisfy user demands.

In order the port authority to function as a 'smart' institution, it can undertake initiatives that redefine the operational framework and develop action frameworks that help to overcome inefficient operations and advance the cooperation of the several stakeholders, including port, logistics and transportation service providers, third parties and port users (Figure 1).

Figure 1 Port value chain stakeholders

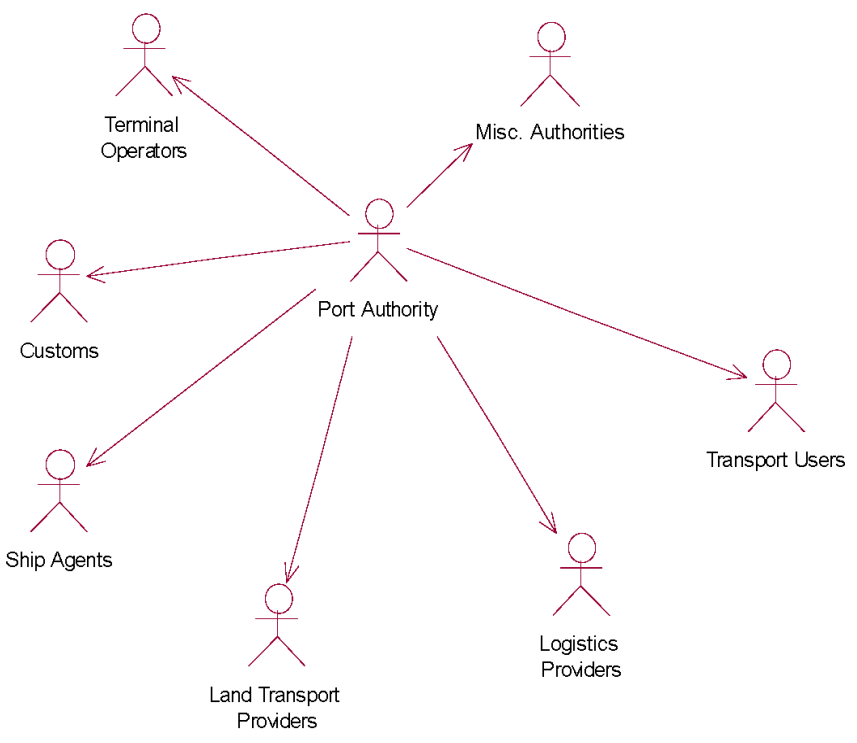


Via networking, port authorities have the potential to overcome decisional and operating fragmentation generated by individual self-interest actions by firms and coordinate actions towards customer-oriented structures of integrated port services according to users' context and situations.

An important component in the different port governance and service provision models is the information and communication services that support the port sector restructuring and product offerings. Although, to a certain extend, this is already realised by some port authorities (Port of Halifax, 2006), port stakeholders' electronic networking forms and outcomes are yet to broadly materialise.

\section{Electronic port governance: the framework}

The e-Government wave has caught the attention of not only the software and consultant industry, but also the policy institutions, the public administration, and a constantly increasing number of researchers. Although there was solid research on ICT in government during the 1970s, 1980s and 1990s, fundamental new research perspectives have been introduced with the current e-Government wave.

E-Government defined as the facilitation or transformation of governmental and public administrative functions and activities enabled by ICTs, entail applications that range from general front-end services (i.e., ministry of transportation one-stop portal) to back-office automation (i.e., public ports document management systems) and intergovernmental services integration. Emerging are also ICT applications directed towards policy input and citizen/customer involvement. In essence, as national e-Government strategies are implemented, strategic public management priorities, such as transparency, accountability, anticorruption and enhanced citizen participation are promoted, transactions are becoming faster and more effective and information quality improves (Fountain, 2001; Wimmer, 2002; OECD, 2005).

Today, public agencies need to move beyond the concept of separate and distinct entities by starting to see themselves as one holistic government that collaborates, shares information, and leverages on the collective knowledge, with the aim being to provide the general public or particular constituencies with better and integrated services in a convenient, continuous, agile and adaptive manner that enhances innovative and collaborative practices (Ke and Wei, 2004).

Successful interorganisational collaborations in e-Government require due respect for the interests and expectations of each participating entity, without introducing obvious threats or unnecessary speculations that challenge its existence or autonomy (Fountain, 2001). In this vein, adjustments are inevitable for balancing the respective organisations' objectives and constraints and can be better reached with an adequate institution structure in place.

The significance of cross agency collaborations in e-Government singles out the importance of an institutional framework for explicitly stipulating the collaborative (working) relationships among autonomous entities, public or private that participate in an e-Government initiative (Dawes and Prefontaine, 2003). To provide and deliver online seamless, one-stop services, the participating actors have to collaborate, streamline, and integrate the respective services and operations, which historically have been departmentalised, or in the case of sectors as ports were provided by a single organisation rather than multiple due to the application of the linear mass services production system. 
'One-stop service' is not a novel concept (Wimmer, 2002; Lambrou, 2003). In fact it has been exploited in the e-Government domain, as an innovative model, in particular within a framework that supports

- $\quad$ leadership and management control at all different levels, and provides

- defined rules and procedures to the overall decision making

- the mutual adjustments of the participating actors (Jen-Hwa Hu et. al., 2006).

The preceded elements are required for reaching and enhancing consensus and building trust among participants.

During the last decade, and in parallel with the development and spreading of ICT, government agencies have leveraged tools and new collaboration between agencies, to a considerable extent. A consolidation of paradigms is needed, however, in order to establish a clear baseline and wide consensus on concepts and terminology and good practices for e-Government in the near future. Against this background, future, innovative scenarios for e-Government initiatives are necessary. Deeper understanding of the complex interplay of technological, organisational, and social factors and processes in both e-Business and e-Government might lead to practice-relevant, cross fertilisation and improve our understanding of the nature and origins of both similarities and differences between the evolutionary trajectories of the two public-private spheres (Scholl, 2006).

\subsection{Port authority centred e-markets}

We argue hereafter that the available theory and empirical results on e-market models (Fountain, 2001) may serve as an appropriate policy-making basis and tool in order to rationalise and determine port interorganisational networks centred on a revamped port authority role; actually this paradigm is in accord with the contemporary port governance and policy restructuring, where the simultaneous presence of both public and private forms of port operations, which are governed by public or quasi-public port authorities is emerging and port authorities are seen as the perfect 'cluster port manager' (de Langen, 2003, 2004).

The proliferation of B2B e-markets has generated a growing academic interest in the phenomenon and although its applicability and ramifications are still not conclusively studied and understood, a plurality in design and operation options is apparent. An e-market is defined as a system that allows market participants to exchange information about prices and product offerings electronically and conduct business transactions (Granados et al., 2007; Gottschalk and Abrahamsen, 2002; Kaplan and Sawhney, 2000; Chircu and Kauffman, 2000; Malone et al., 1987). As Lee et al. (2004) outline in a thorough overview of concepts, taxonomies and possible instances of e-markets, e-markets are designed to exploit certain market opportunities, while individual e-market types differ from one another with respect to their target users, underlying market structures and respective ownership, product/service offerings, value propositions and provided functionality.

Hence, based on established taxonomies and models one can envisage the existence of a port e-market paradigm where port supply and demand is aggregated, matched and facilitated via an institutional e-Governance infrastructure that ensures meaningful port interorganisational network relationships between the various actors related to one port cluster. 
A framework present by Gosain and Palmer (2004) conceptualises e-markets as network orchestrators that generate value by creating exchange opportunities and facilitating economic and social exchanges.

On these grounds a port-authority centred e-market might be the mean for orchestrating three types of network linkages that create value for their participating organisations in three distinct ways:

- orchestration of information linkages (i.e., communication) that result in improving information exchange and the processing of port operation-related information (such as vessel prearrival notifications, cargo-handling information, customs declaration information, etc.)

- orchestration of value linkages that result in improving transactional characteristics that drive change in port stakeholders' organisation and operational integration (such as electronic process integration, port-based intermodal transportation and logistics services and transactions coordination and execution)

- orchestration of relational (i.e., socioeconomic integration) linkages that result in improving social, economic and political relationships and make available resources embedded in these port stakeholders relationships.

The expected benefits of using e-markets, or the underlying motivational factors, are seen for both the buyers and the suppliers participating in an e-market.

Regarding the intention to participate in interorganisational networks, Cheng et al. (2006) explore in particular the moderating effect of intention to e-collaborate on governance mode. They argue that the intention to e-collaborate will moderate the effects of the three decision contexts, namely the threat of opportunism, the threat of commercial failure, and the opportunity for sustainable advantage, on the two identified governance modes (e-collaboration vs. arms-length relationship).

Reviewing the literature on motives for participating in e-market activities, Rask and Kragh (2004) conclude that there is a matrix with four types of motivating factors for using and/or participating - namely, efficiency, positioning, exploration and legitimacy - which are based upon the dimensions of drivers (internal vs. external) and the nature of the decision (planned vs. emerging). Based on the aforementioned frameworks, we adapt our postulation regarding port-authority-centred e-markets models, in order to determine the possible port service providers' and port users' motives for taking up e-markets activities (Figure 2):

- More specifically, the efficiency motive accounts to a decision to participate in e-markets which is driven by an internal objective to obtain organisation-specific advantages. More precisely, port users can be highly motivated by process efficiency, particularly in terms of reducing time, increase reliability, deploy new strategies corresponding to a globalised trade environment (i.e., hub and spoke practices), but also in terms of achieving lower prices. Port service providers are expected also to show interest in reducing process time and costs, and increase services efficiency, in terms of specifying parts of the operation in which they should focus and implement novel concepts (i.e., just-in-time, door-to-door services) demanding integration with spatially separated (regionalised) complementary entities. 
- Positioning appears as a strong reason for both port service providers and port users to participate in e-markets. The port sector dynamic economic context and the continuous alteration of the port competitiveness hierarchy are driving forces towards participation in e-markets. Port authorities, public administrations, port service providers and port users, are all actors interested to increase their positioning within a port complex. At the same time they are interested in the overall positioning of this complex vis-à-vis other ports competing for the same region. The positioning motive is important in order to increase both market reach and potential.

- As regards the motive of legitimacy, e-market participation can be driven by external factors rooted in the relationships of an organisation in the port value chain with other organisations, and may occur as the result of ongoing negotiations between port governors, operators and/or users. The legitimacy motive is very real for many port service providers, especially in terms of their eagerness to follow existing customers.

- Exploration is a possible motive for port actors as well. To some extent, port service providers, in particular, might base initial e-market participation on trial and error, with the decision to continue participation being a direct result of actual experiences.

Figure 2 Port-centred e-markets framework

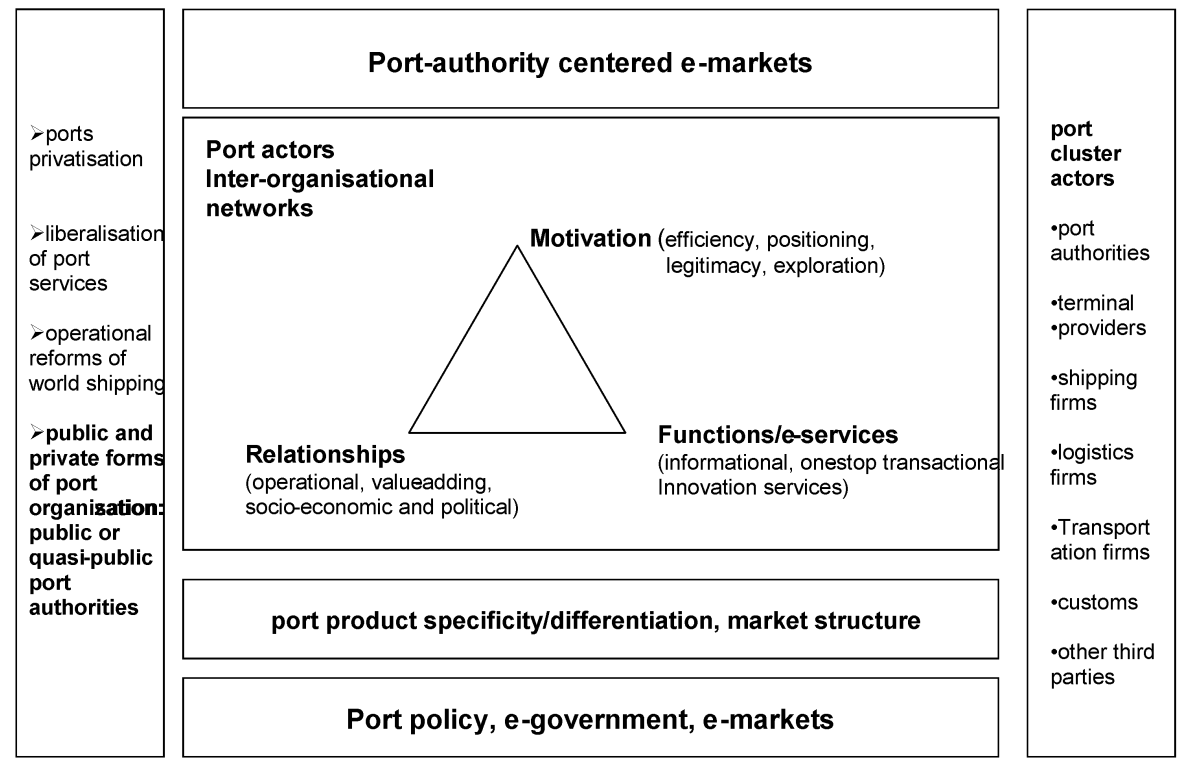

\subsection{Port e-markets typology}

Caputo et al. (2004) proposed an integrated model that allows to identify the more appropriate set of organisational structures, managerial criteria and critical activities, based on variables characterising the environment in which an e-supply chain is embedded. 
Yang et al. (2007), explore, in broader terms, the feasibility of applying an internet-based information system to facilitate business alliance activities, and they conclude that communication and information sharing are the most appropriate activities in business alliances for the application of an internet-based information system, whereas the decision to adopt an internet-based information system is dependent on the allied partners' support and the technological capabilities they possess.

As far as the transportation sector, in particular, is concerned, Song and Regan (2001) provided a general overview of the features, trends and the market situation regarding freight transportation e-markets/intermediaries. $\mathrm{Li}$ and Shue (2003) proposed a framework for developing an air cargo infomediary and outline the impact and benefits it accrues to the cargo logistics chain. Granados et al. (2007) present a theoretical framework and apply it to the air travel industry, arguing that determinants such as public policy, product characteristics that favour electronic trading and competitive (market) and institutional forces that promote industry competitiveness enable the move to transparent (air travel) markets.

As Sharifi et al. (2006) argue a strategic framework for the identification and selection of an appropriate e-marketplace approach can include a classification model, the key dimensions of which are the nature of the products/services to be traded, the ownership/formation of the marketplace and the level of functionality/relationships exhibited by the trading exchange.

Hence, based on the aforementioned arguments, we postulate that port authority-centred e-markets can act as catalysts for efficient port product trading. The nature and complexity of the port product, in terms of its high degree of variation and specialisation, as well as its time, price and brand sensitivity favour an e-marketplace appropriateness.

In terms of ownership, a market can be characterised as independent (vendor led), sector coalition (sector led) or privately owned (Sharifi et al., 2006). Lee et al. (2004) determine certain features of particular e-market types, including the Industry-Sponsored e-Markets (ISMs), the third-party exchanges (3PXs) and private e-marketplaces.

Against this background, we envisage two applicable models, considered as e-hubs for port sectoral operations execution:

- port industry-sponsored e-markets defined as consortia e-markets cofounded by port sector leaders (such as private port operators and public port authorities)

- port third-party exchanges defined as neutral e-markets founded by a port authority, where a number of participants both at the supply and at the demand side (many-to-many) are performing information exchange and electronic port transactions, centred on aggregating fragmented supply and demand for greater market efficiency (Table 1).

Port industry-sponsored e-markets and port third-party exchanges can operate either as public e-marketplaces or on a mixed mode basis offering both public e-markets services, open to all qualified participants, and private e-markets services, available to a closed set of participants; this model is in contrast to a third type of e-market that is a private e-market which is built by a leading port service supplier (i.e., terminal operator) or a port service buyer (i.e., shipping company) to link itself with its own group of port business partners. 
Table 1 Port-authority-centred e-markets

\begin{tabular}{|c|c|c|}
\hline $\begin{array}{l}\text { Electronic port } \\
\text { governance models }\end{array}$ & $\begin{array}{l}\text { Port authority centred } \\
\text { e-markets functions }\end{array}$ & $\begin{array}{l}\text { Port authority centred e-markets value } \\
\text { proposition }\end{array}$ \\
\hline \multirow[t]{11}{*}{$\begin{array}{l}\text { Port industry- } \\
\text { sponsored e-markets }\end{array}$} & $\begin{array}{l}\text { Cargo and passenger handling } \\
\text { e-services }\end{array}$ & $\begin{array}{l}\text { Port services supply and demand } \\
\text { aggregation/integration }\end{array}$ \\
\hline & $\begin{array}{l}\text { Pilotage and towage } \\
\text { e-services }\end{array}$ & $\begin{array}{l}\text { Port services demands and offers } \\
\text { matching }\end{array}$ \\
\hline & $\begin{array}{l}\text { Customs and immigration } \\
\text { e-services }\end{array}$ & Market transparency \\
\hline & $\begin{array}{l}\text { Vessel traffic services and } \\
\text { safety e-services }\end{array}$ & $\begin{array}{l}\text { Trust, facilitation and interests } \\
\text { settlement }\end{array}$ \\
\hline & $\begin{array}{l}\text { Maintenance and repair } \\
\text { services e-services }\end{array}$ & Efficiency \\
\hline & Waste disposal & Reach \\
\hline & Landside and berth e-services & $\begin{array}{l}\text { Protection of public interest on behalf } \\
\text { of the port community }\end{array}$ \\
\hline & $\begin{array}{l}\text { Logistics and hinterland } \\
\text { e-services }\end{array}$ & $\begin{array}{l}\text { Determination of port policy, and } \\
\text { safety and environment policies } \\
\text { applicable }\end{array}$ \\
\hline & $\begin{array}{l}\text { Facilities, freight, passenger } \\
\text { security e-services }\end{array}$ & $\begin{array}{l}\text { Negotiation capabilities and } \\
\text { participatory modes of port governance }\end{array}$ \\
\hline & Emergency e-services & \\
\hline & E-marketing of operations & \\
\hline \multirow{10}{*}{$\begin{array}{l}\text { Port third-party } \\
\text { exchanges }\end{array}$} & Port service search & \\
\hline & Port service reservation/order & \\
\hline & Status tracking & \\
\hline & Port service catalogue & \\
\hline & $\begin{array}{l}\text { Port service negotiations and } \\
\text { auctions }\end{array}$ & \\
\hline & Port service provider search & \\
\hline & Back-end integration & \\
\hline & Port supplier buyer rating & \\
\hline & RFQ & \\
\hline & Collaborative planning & \\
\hline
\end{tabular}

Port industry-sponsored e-markets may emerge where a few large port service providers or port users can bring along substantial volume of business (Lee et al., 2004). Their presence can make a port industry-sponsored e-market appear one sided and less appealing to other port market participants. Port industry-sponsored e-markets hold an advantage not available to port third-party exchanges: ready access to the large trading volume of their founders that can help them build market liquidity. A bigger advantage for port industry-sponsored e-markets may lie in their position in the supply chain. When industry leaders are among their founders, port industry-sponsored e-markets seem well placed to facilitate the development of uniform standards for transmitting data, describing products and coordinating business processes, as well as to gain wide commitment to a common information platform.

Taking into account these postulations, when the public port authority assumes the role of a port cluster manager interested in investing and promoting port innovation and efficiency, it is worth considering and developing port-authority-centred e-markets, 
following a hybrid port-industry-sponsored e-market or port third-party exchanges model as a platform for supply chain integration that fosters port crossorganisational collaboration for strategic advantage, depending on the actual embeddedness of port actors' networks in political, structural, economic and institutional factors.

Regarding the functionality of a port-authority-centred e-market, it comprises e-services whereby port supply chain actors can be informed, communicate, and transact, thus including informational, transactional and value-adding, innovative port e-services, namely port service search, port service reservation/order, status tracking, port service catalogue, port service negotiations and auctions, port service provider search, back-end integration, port supplier buyer rating, request for proposal/quotation and collaborative planning.

\section{Conclusions and future work}

The paper provides a conceptual framework for electronic port e-Governance integrating arguments from two different strands and theories

- the contemporary policy, organisational, operational and technological issues and trends in the port sector

- the converging elements of e-Government and e-markets.

The emerging hybrid form of port organisation, involving a plurality of port actors provides a dynamic sectoral paradigm that creates incentives for interorganisational collaboration and operational synchronisation. Specific e-market models can work towards this direction, whilst a public port authority is situated in a central role for promoting in practice the efficiency of a port cluster.

A port might benefit if the port authority employs new ICTs and operational models, in specific e-market models and act as the 'smart' institution that governs the implementation of network organisational forms (Chlomoudis and Pallis, 2004; van der Lugt and de Langen, 2007). This development would redefine the operational framework and help to overcome inefficient operations, and advance the cooperation of the several port stakeholders. Port-authority-centred e-markets contribute to overcome decisional and operating fragmentation and coordinate actions towards customer-oriented structures of integrated port value chains.

The presence of multiple service providers leads to the expansion of the geographically concentrated, mutually related, business units, associations and public-private organisations that are centred on a port complex. Relationships become perplexing and port governance demands the management of numerous (internal, external, public policy and community) stakeholders' relations.

Port studies, in particular those examining port governance (Brooks and Cullinane, 2006) have recognised the importance of stakeholders' relations and the operation of networks arrangements among distinct but related firms as a mean to promote the overall performance of the emerging port clusters. In this vein, scholars have acknowledged the need for port-authority-centred strategies in order to promote stakeholders' interactions, by expanding the efficiency and the effectiveness of the relevant coordination. This is not least because coordination of actors in supply does not always arise spontaneously. For instance (van der Horst and de Langen, 2007), there might be a lack of contractual 
relationships, information asymmetry, and the lack of practical incentives or optimum platforms for cooperation developments. What is still to be answered is what forms of technologically driven concepts might facilitate the transformation of the theoretical approaches to actual practices, and how. It is this gap in the literature that this exploratory study has attempted to contribute in.

Overall, 'networking' as based on the advancement of a rational coordination, for operating and strategically developing a port, with core features as outlined in the port-authority-centred e-market paradigm, can revamp port authorities in a new blended virtual agency role, that is a combined physical and electronic mode of operation. The port-authority-centred e-market paradigm supports the role of the port authority as a 'network orchestrator' that acts with positive network externalities for its participants.

Given that the port authority performance is by definition related to the performance of the whole port cluster, the authority has incentives to invest in action frameworks that enhance the performance of the network, in particular the enactment of port-authority-centred networks supported by ICTs and the proposed port e-markets models. Especially as the users of ports are increasingly familiar with this concept (for the case of shipping lines see: Lambrou. and Nikitakos, 2007).

Thus, the present paper proposes a unified and theoretically robust framework in order to offer a systematic basis for diagnosing applicable modes in port governance, as based on innovative ICTs. The presented framework serves as a port policy and decision-making tool regarding port performance and competitiveness via the enactment of e-services and e-Governance models. The paper establishes the significance and the applicability of advanced port e-Governance models, based on e-markets typologies and world wide, emerging port sector practices, so as to facilitate knowledge transfer targeting policy makers, decision makers and port professionals in developed or developing areas, concerning large- or small- and medium-sized port settings. The proposed framework provides a systematic basis of applicable, innovative e-Governance modes, in particular the port-authority-centred e-market types considered, focusing on stakeholders' motivation, supported relationships and provided functions, within port organisations.

The next step is to empirically examine the motives, relationships, important functions and value propositions specified in the model by means of an empirical survey, in varying port market settings. The present research contributes to the existing port policy and e-Government literature by developing an integrated model for port actors' e-collaboration and ports e-Governance. By empirically supporting the proposed relationships and modes of operation, we can derive possible mechanisms to improve port actors' performance and competitiveness, via ICT-enacted reciprocity.

\section{References}

Baltazar, R. and Brooks, M.R. (2006) 'Port governance devolution, and the matching framework: a configuration theory approach', in Brooks, M.R. and Cullinane, K. (Eds.): Devolution, Port Governance and Port Performance, Research in Transport Economics, Elsevier, London, Vol. 17, pp.379-403.

Bichou, K. and Gray, R. (2005) 'A critical review of conventional terminology for classifying seaports', Transportation Research Part A, Vol. 39, No. 2, pp.75-92.

Brooks, M. (2004) 'The Governance structure of ports', Review of Network Economics, Vol. 3, No. 2, pp.168-183. 
Brooks, M.R. and Cullinane, K. (2006) Devolution, Port Governance and Port Performance, Vol. 17, Research in Transport Economics, Elsevier, London.

Caputo, A.C., Cucchiela, F., Fratocchi, L., Pelagagge, P.M. and Scacchia, F. (2004) 'Analysis and evaluation of e-supply chain performances', Industrial Management and Data Systems, Vol. 104, No. 7, pp.546-557.

Cheng, E., Love, P., Standing, G. and Gharavi, H. (2006) 'Intention to e-collaborate: propagation of research propositions', Industrial Management and Data Systems, Vol. 106, No. 1, pp.139-152.

Chircu, A.M. and Kauffman, R.J. (2000) 'Reintermediation strategies in business-to-business electronic commerce', International Journal of Electronic Commerce, Vol. 4, No. 4, pp.7-42.

Chlomoudis, C.I. and Pallis, A.A. (2004) 'Port governance and the smart port authority: key issues for the reinforcement of quality services in European ports', Proceedings of the 10th World Conference on Transport Research, June, Istanbul, Turkey (CD-Rom).

Chlomoudis, C.I., Karalis, V.A. and Pallis, A.A. (2003) 'Port reorganisation and the worlds of production theory', European Journal of Transport and Infrastructure Research, Vol. 3, No. 1, pp.77-94.

Cullinane, K.P.B. and Song, D.W. (2002) 'Port privatisation policy and practice', Transport Reviews, Vol. 22, No. 1, pp.55-75.

Dawes, S.S. and Prefontaine, L. (2003) 'Understanding new models of collaboration for delivering government services', Communications of the ACM, Vol. 46, No. 1, pp.40-42.

de Langen, P.W. (2003) 'The port authority as cluster manager', Proceedings of the 2nd International Conference on Maritime Transport, Technical University of Catalonia, Barcelona, Spain, November, pp.67-84.

de Langen, P.W. (2004) 'Governance in seaport clusters', Journal of Maritime Economics and Logistics, Vol. 6, No. 2, pp.141-156.

de Langen, P.W. and Pallis, A.A. (2006) 'The effects of intra-port competition', International Journal of Transport Economics, Vol. XXXIII, No. 1, pp.69-85.

European Commission (2004) Proposal for a Directive of the European Council and the European Parliament on Market Access to Port Services, Com (2004) 654, final, 13.10.2004.

Fountain, J.E. (2001) Building the Virtual State: Information Technology and Institutional Change, Brookings Institution Press, Washington DC.

Gilman, S. (2003) 'Sustainability and national policy in UK port development', Maritime Policy and Management, Vol. 30, No. 4, pp.275-291.

Gosain, S. and Palmer, J.W. (2004) 'Exploring strategic choices in marketplace positioning', Electronic Markets, Vol. 14, No. 4, pp.308-321.

Gottschalk, P. and Abrahamsen, A. (2002) 'Plans to utilize electronic marketplaces: the case of B2B procurement markets in Norway', Industrial Management and Data Systems, Vol. 102, No. 6, pp.365-331.

Granados, N., Gupta, A. and Kauffman, R.J. (2007) 'IT-enabled transparent electronic markets: the case of the air travel industry', Information Systems and e-Business Management, Vol. 5, No. 1, pp.65-91.

Helling, A. and Poister, T.H. (2000) 'US maritime ports: trends, policy implications, and research needs', Economic Development Quarterly, Vol. 4, No. 4, pp.300-317.

Jen-Hwa Hu, P., Cui, D. and Sherwood, A.C. (2006) 'Examining cross-agency collaborations in e-government initiatives', Proceedings of the 39th Hawaii International Conference on System Sciences, Hawaii (CD-Rom).

Kaplan, S. and Sawhney, M. (2000) 'E-hubs: the new B2B marketplace', Harvard Business Review, Vol. 78, pp.97-103.

Ke, W. and Wei, K.K. (2004) 'Successful e-government in Singapore', Communications of the $A C M$, Vol. 47, No. 6, pp.95-99. 
Kia, M., Shayan, E. and Ghotb, F. (2000) 'The importance of information technology in port terminal operations', International Journal of Physical Distribution and Logistics Management, Vol. 30, No. 3, pp.331-344.

Lambrou, M.A. (2003) 'Advancing the one-stop shop e-government paradigm', Proceedings of the IEEE International Engineering Management Conference, NY, USA, pp.489-493 (CD-Rom).

Lambrou, M.A. and Nikitakos, N. (2007) 'Digital shipping: the Greek experience', in Pallis, A.A. (Ed.): Maritime Transport: The Greek Paradigm, Research in Transport Economics, Elsevier, London, Vol. 17, pp.383-417.

Lee, T.T., Rao, S.S. and Truong, D. (2004) 'Industry-sponsored marketplaces: a platform for supply chain integration for a vehicle for market aggregation', Electronic Markets, Vol. 14, No. 4, pp.295-307.

Li, S. and Shue, L., (2003) 'A study of logistics infomediary in air cargo tracking', Industrial Management and Data Systems, Vol. 103, No. 1, pp.5-13.

Malone, T.W., Yates, J. and Benjamin, R.I. (1987) 'Electronic markets and electronic hierarchies', Communications of the ACM, Vol. 30, No. 6, pp.484-497.

Mogli, F. and Sanguineri, M. (2003) 'Port planning: the need for a new approach', Journal of Maritime Economics and Logistics, Vol. 5, No. 4, pp.413-425.

Moonen, H., van der Rakt, B., Miller, I., van Nunen, J. and van Hillegesrberg, J. (2005) Agent Technology Supports Inter-Organizational Planning in the Port, Report of the Erasmus Research Institute of Management, Rotterdam.

Notteboom, T.E. and Winkelmans, W. (2001) 'Structural changes in logistics: How will port authorities face the challenge?', Maritime Policy and Management, Vol. 28, No. 1, pp.71-89.

Notteboom, T.E. and Winkelmans, W. (2002) 'Stakeholder relations management in ports: dealing with the interplay of forces among stakeholders in a changing competitive environment', Proceedings of the IAME Conference, Panama City, Panama (CD-Rom).

OECD (2005) The e-Government Imperative: Main Findings, Policy Brief Report, URL: http://www.oecd.org/dataoecd/60/60/2502539.pdf, accessed 20 January 2007.

Paixao, A.C. and Marlow, P.B. (2003) 'Fourth generation ports - a question of agility?', International Journal of Physical Distribution and Logistics Management, Vol. 33, No. 4, pp.355-376.

Pallis, A.A. and Vaggelas, G.K. (2005) 'Port competitiveness and the EU 'Port Services' directive: the case of Greek ports', Maritime Economics and Logistics, Vol. 7, No. 2, pp.116-140.

Port of Halifax (2006) The Smart Port Vision, URL: www.smartport.ca, accessed 10 January 2007.

Rask, M. and Kragh, H. (2004) 'Motives for e-marketplace participation: differences and similarities between buyers and suppliers', Electronic Markets, Vol. 14, No. 4, pp.270-283.

Robinson, R. (2003) 'Ports as elements in value-driven chain systems: the new paradigm', Maritime Policy and Management, Vol. 29, No. 3, pp.241-255.

Rodrigue, J.P. (2005) 'New port-hinterland relationships: experiences from North America', Proceedings of the International Workshop on New Generation Port Cities and Global Supply Chains, The University of Hong Kong, China (CD-Rom).

Rodrigue, J.P. and Notteboom, T.E. (2005) 'Port regionalization: towards a new phase in port development', Maritime Policy and Management, Vol. 32, No. 3, pp.297-313.

Scholl, H.J. (2006) 'What can e-commerce and e-government learn from each other?', Proceedings of the 2006 International Conference on Digital Government Research, pp.454-455.

Sharifi, H., Kehoe, D. and Hopkins, J. (2006) 'A classification and selection model of e-marketplaces for better alignment of supply chains', Journal of Enterprise Information Management, Vol. 19, No. 5, pp.483-503.

Song, J. and Regan, A.C. (2001) 'Transition or transformation? emerging freight transportation intermediaries', Transportation Research Record, Vol. 1763, pp.1-5.

Suykens, F. and van de Voorde, E. (1998) 'A quarter of a century of port management in Europe: objectives and tools', Maritime Policy and Management, Vol. 25, No. 3, pp.251-262. 
van der Horst, M. and de Langen, P.W. (2007) 'Coordination in Hinterland transport chains: a major challenge for the seaport community', Proceedings of International Association of Maritime Economists 2007 Conference, Athens, Greece (CD-Rom).

van der Lugt, L. and de Langen, P.W. (2007) 'Port authority strategy: beyond the landlord - a conceptual approach', Proceedings of International Association of Maritime Economists 2007 Conference, July, Athens, Greece (CD-Rom).

Wimmer, M.A. (2002) 'Integrated service modeling for online one-stop Government', Electronic Markets, Vol. 12, No. 3, pp.1-8.

World Bank (2000) Port Reform Tool Kit, World Bank Report.

Yang, M., Liao, C. and Liu, S. (2007) 'Applying internet-based information systems to facilitate business alliance activities', Industrial Management and Data Systems, Vol. 107, No. 1, pp. $125-140$ 